International Journal of Engineering \& Technology, $7(3.2)(2018) 169-175$
International Journal of Engineering \& Technology
Website: www.sciencepubco.com/index.php/IJET
Research paper

\title{
Construction Work Cost Determination
}

\author{
Olena Koba ${ }^{1}$, Yulia Myronova ${ }^{2}$, Volodymyr Byba ${ }^{3 *}$ \\ ${ }^{1}$ poltava National Technical Yuri Kondratyuk University, Ukraine \\ ${ }_{2}^{2}$ poltava National Technical Yuri Kondratyuk University, Ukraine \\ ${ }_{3}^{3}$ poltava National Technical Yuri Kondratyuk University, Ukraine \\ *Corresponding Author E-Mail: Bibavv1@Ukr.Net
}

\begin{abstract}
The main Ukraine construction industry tendencies during 2010-2017 are described in the article. The order of construction and installation work formation is determined. The practical application peculiarities of cost calculations traditional and alternative methods in construction industry are considered. Based on the principles, methods and tools created a new conceptual model construction work cost determination.
\end{abstract}

Keywords: calculation methods, construction and installation work cost, construction industry, costs, financial statements.

\section{Introduction}

The construction industry affects the efficiency of the functioning of the whole country economic management system. It provides creation and restoration of fixed assets for business entities and population. The construction industry is an important development element: production of building materials and equipment, machine building, metallurgy, petrochemicals, wood processing industry, transport, energy, which leads to economic growth of the country and solving many social problems.

The scientific works of domestic and foreign scientists, in particular: A. Apcherch, P. Atamas, V. Bondar, P.S. Bezrukykh, F.F. Butynets, Ya.I. Huralnyk Z.V. Hutsailiuk, V.A. Deriia, K. Druri, Z.-M.V. Zadorozhnyi, V.A. Iliashenko, Ya.D. Krupka, B.M. Lytvyn, N.M. Maliuha, N.V. Muzhevych, I.S. Matskevichius, L.V. Napadovska, V.V. Sopko, M.S. Pushkar, Yu.S. Tsal-Tsalko, M.H. Chumachenko and others are devoted to construction cost accounting and cost formation research. Their scientific achievements have become the basis for further improvement of accounting for production costs at construction enterprises.

However, there are some problem issues of the composition cost formation, the order of their accounting in construction, the use of calculation methods which require a more detailed discussion.

O. Pavlenko [1] focuses on the problems of cost accounting, the formation of reliable information on the cost construction and installation works of non-compliance of regulatory documents that regulate accounting costs of the construction company. The author notes that the classification of expenses by activities types is not comparable in accordance with H(P)AS 1 "General requirements for financial reporting" and problems of the ordinary activity expenses, operational, basic and extraordinary activities, which are recorded in "the Methodological recommendations on the cost formation of construction and installation work".

Verkhohliadova N.I., Borodin M.O., Nehoda A.S. [4] allocate components of the construction cost and installation work: materi- als, labor costs, maintenance and operation costs of construction machinery and machinery, overhead costs. In their opinion, the main factors of reducing the cost are: increasing productivity, reducing the duration of construction, economical spending of material and cash and eliminating unproductive costs and losses; introduction of new equipment, improvement of material and construction technical support, improvement of organizational structure of contracting construction and assembly organizations, their consolidation and specialization, training of builders.

O.Ie. Kononova, K.I. Prosenko [5] offer to detail the article "Overhead" and propose the new classification of expenses items for construction companies: materials, transportation costs for materials delivery, labor costs for production personnel, deductions for social needs, maintenance and maintenance costs for construction machinery, and mechanisms, administrative and managerial expenses, overhead costs of structural subdivisions, general construction overhead costs, expenses for the organization of works on building sites, security guards but the environment, other overheads. The new system of classification guarantees correct allocate actual costs between individual types of construction and installation work, increase the interest of organizations in reducing the management cost and service of the enterprise.

V.A. Iliashenko, Yu.O. Yukhnovska [6] propose to add the article: "Costs for repayment of tax liabilities", "Imported materials" for the nomenclature of articles on production costs in construction. As results, the adoption effectiveness of managerial decisions and profit of the industry will be increased.

There are many problems of costs classification in the construction industry. T.V. Davydiuk [7], K. Radchenko [8], M.I. Skrypnyk [9] recommend to improve the procedure for calculating the cost of production in various sectors of the economy.

N.M. Pyrets, T.S. Chernenko [10] recommend to apply in the construction industry normative, extra-language, preliminary methods. Also, the choice of the method of calculation is dependent by the construction production organization, technological features, type of works. 
Jianqiang Tang [11], Carolin Bahr, Kunnibert Lennerts [12], Agnieszka Leśniak, Edyta Plebankiewic, Krzysztof Zima [13] agree this view.

T. Ivanytska [14] proposes the classification of cost production calculation for the purpose of accounting, control and cost management by analyzing the methods of cost accounting and the cost production calculation in general, and, in particular, the enterprises of the construction industry. Also, the author considers the possibility of using in the construction industry modern methods of cost management. This are methods: "exactly in time", targetingcosting, Kaiser-Costing, benchmarking, TQM, strategic cost accounting or "on the stages of life cycle".

As result, the problem of improving classical methods and introducing the latest methods of calculation is actual and determines the choice of the research topic.

\section{Main Body}

For the last three years construction industry of Ukraine got a very big boost to development. According to the results of 2017, Ukrainian enterprises completed construction works worth UAH 105,682.8 million. (Table 1), the index of construction products in relation to 2016 was $126.3 \%$ (Table 2) [15]. The new construction, reconstruction and technical re-equipment amounts to $73.2 \%$ of the total amount of executed construction works, overhaul and maintenance work $-17.1 \%$ and $9.7 \%$ respectively. According to the results of the year, the construction of engineering structures increased by $48.3 \%$, buildings - by $38.6 \%$.

The growth of the construction industry is typical for all regions of Ukraine. Kharkiv, Dnipropetrovsk, Poltava, Kyiv, Lviv, Odesa regions become leaders in terms of volume (Table 3 ).

However, according to the Ukraine's rating in Doing Business Index (Table 4), despite the positive developments, registration, crediting, investment and quality of monitoring in the construction sector issues are still problematic [18]. Solving these issues requires the availability of human, material and information resources. An important information resources element of the construction sector is the accounting and analytical information on cost management and prime cost formation of construction and installation work.

The problem of the cost qualitative calculation has an important place in the economy of construction as a whole and is sufficient for the understanding of the effective building resources use in the production process.

Cost (prime cost) is a generalized economic indicator that characterizes the results of production and economic activity of the construction company. It is the main factor in generating profits and funds for employees material encouragement.

The organization and Prime Cost Calculation Method are influenced by the following features of the construction process implementation [5]:

- organizational (no requirements for storage and transportation of construction products, mobility of construction organizations, material and labor resources, individual character and uniqueness of each construction object, variety of executed types of construction works, the need to build temporary titular and non-titular facilities for the provision of socio- living conditions for workers, involved in the work of subcontract organizations, the existence of objectively determined breaks in the occupation of specialized construction companies or specialized teams, the significant influence of the personnel qualifications as a managerial (at the stage of preparation and implementation) so production (in the fulfilment process of construction and installation works) on the safety of the construction site further exploitation, a large number of participants and the complex process of document management, territorial division of the construction company administration and manufacturing, etc.);

- technical production (duration of the operating cycle, significant amount of unfinished construction, production processes unity and construction products sale, dependence of the construction process on climatic and natural conditions, reduction of the construction quality and installation works, involvement of low-skilled workers, etc.);

- economic (individual pricing order on the basis of specific budget documentation, estimation complexity of economic efficiency of accepted organizational, technical and managerial decisions due to the considerable duration of construction projects realization).

The cost of construction and installation work carried out by the construction company includes costs for the purchase of materials, fuel, energy, wages of hired workers, compensation for the depreciation of fixed assets, as well as costs associated with the peculiarities of technology, organization and management of building production, control of production processes and objects construction quality.

There are different methods of accounting for production costs and calculation of the production cost. Their application is determined by the peculiarities of the technological process, the nature of the manufactured products (works, services provided), its composition, the way of processing.

The choice of the cost accounting and cost calculation methods depends on the specific task facing the company's management.

There are three traditional costing approaches used in construction industry, namely costing process, job order costing and normative, the characteristics of which are represented in Table 5.

Depending on the calculating objects choice, the process costing and job order costing methods of calculation are usually distinguished.

Calculation by processes (redistribution) assumes grouping of costs within separate processes or stages of manufacture with their future accounting. Such a system is typical for mass and serial production. Its complexity depends on the features of the technological process (number of units, sequence or parallelism of the processing) and the availability and size of the work in progress (Figure 1).

The job order method of cost accounting is used in the unique objects construction or the execution of works under a special order. Its essence is that all direct costs are accounted for by individual production orders (cards). Indirect costs are accounted for by the place of their occurrence and added to the cost by distribution in proportion to a selected base. With this method, the object of cost accounting and the object of calculation is a single order. The type of order is determined by the contract with the customer. It specifies the cost, payment arrangements, the transfer of products (works, services), the duration of the order. By the time the order is executed, the incurred costs for the given object are considered incomplete production (Figure 2) [21].

Normative method of accounting and calculating the costs of production is characterized by the fact that the previous normative calculation at the enterprise is done for each object (estimated documentation). Normative calculations are calculated on the basis of technically justified rates of material and labour costs. They, in turn, are installed in accordance with the technical documentation for the execution of works (estimate) and form an interconnected system, which regulates all aspects of the enterprise economic activity.

The accounting is organized in such a way that all costs can be divided into costs according to norms and deviations from norms. The provided data allows us to manage the cost of products and at the same time calculate the actual cost by adding to the normative cost (deduction from it) the corresponding share of deviations from the norms for each article (Figure 3). The application of normative accounting in modern conditions in Ukraine is influenced by inflation. In the conditions of inflation, it is very difficult to maintain normative accounting. Cost norms need to be adjusted quarterly, or even monthly, what greatly complicates the calculation procedure.

The successor to the normative method of calculation can be called the "standard costing" method, which is based on the principle of accounting and controlling the costs within the established norms, standards and deviations from them. When applying this method, excessive costs are related to financial results or to the 
perpetrators, while standards are developed for all types of costs, as well as for income and some production indicators. Despite the obvious advantages of this method, it did not find proper implementation in construction organizations in Ukraine.

Table 1: The volume and structure of completed construction work by construction products types

\begin{tabular}{|c|c|c|c|c|c|c|c|c|c|c|}
\hline \multirow{3}{*}{ Year } & \multicolumn{2}{|c|}{ Construction of all, } & \multicolumn{2}{|c|}{$\begin{array}{r}\text { Buildings } \\
\end{array}$} & \multicolumn{4}{|c|}{ including } & \multicolumn{2}{|c|}{ Engineering structures } \\
\hline & \multirow{2}{*}{$\begin{array}{l}\text { UAH } \\
\text { million }\end{array}$} & \multirow[t]{2}{*}{$\%$} & \multirow[t]{2}{*}{ UAH million } & \multirow[t]{2}{*}{$\%$} & \multicolumn{2}{|c|}{ residential } & \multicolumn{2}{|c|}{ non-residential } & \multirow[t]{2}{*}{ UAH million } & \multirow[t]{2}{*}{$\%$} \\
\hline & & & & & $\begin{array}{l}\text { UAH } \\
\text { million }\end{array}$ & $\%$ & $\begin{array}{l}\text { UAH } \\
\text { million }\end{array}$ & $\%$ & & \\
\hline 1 & 2 & 3 & 4 & 5 & 6 & 7 & 8 & 9 & 10 & 11 \\
\hline 2010 & 42918.1 & 100 & 19659.1 & 45.81 & 6876.5 & 16.02 & 12782.6 & 29.78 & 23259.0 & 54.19 \\
\hline 2011 & 61671.7 & 100 & 26745.4 & 43.37 & 8137.1 & 13.19 & 18608.3 & 30.17 & 34926.3 & 56.63 \\
\hline 2012 & 62937.2 & 100 & 28104.8 & 44.66 & 8523.0 & 13.54 & 19581.8 & 31.11 & 34832.4 & 55.34 \\
\hline 2013 & 58586.2 & 100 & 28257.3 & 48.23 & 9953.1 & 16.99 & 18304.2 & 31.24 & 30328.9 & 51.77 \\
\hline 2014 & 51108.7 & 100 & 24856.5 & 48.63 & 11292.4 & 22.09 & 13564.1 & 26.54 & 26252.2 & 51.37 \\
\hline 2015 & 57515.0 & 100 & 28907.5 & 50.26 & 13908.8 & 24.18 & 14998.7 & 26.08 & 28607.5 & 49.74 \\
\hline 2016 & 73726.9 & 100 & 38106.4 & 51.69 & 18012.8 & 24.43 & 20093.6 & 27.25 & 35620.5 & 48.31 \\
\hline 2017 & 105682.8 & 100 & 52809.6 & 49.97 & 23730.0 & 22.45 & 29079.6 & 27.52 & 52873.2 & 50.03 \\
\hline
\end{tabular}

Developed by the authors for [16]

Table 2: Indices of construction products in Ukraine in 2010-2017,\% to the previous year

\begin{tabular}{|c|c|c|c|c|c|c|c|c|}
\hline Year & 2010 & 2011 & 2012 & 2013 & 2014 & 2015 & 2016 & 2017 \\
\hline 1 & 2 & 3 & 4 & 5 & 9 & 7 \\
\hline $\begin{array}{c}\text { Building prod- } \\
\text { ucts index }\end{array}$ & 94.6 & 118.6 & 9.7 & 88.9 & 79.6 & 87.7 & 117.4 \\
\hline
\end{tabular}

It is generalized by the authors for [16, 17]

Table 3: Volume of executed construction works by construction products types and by region in January-February 2018, mln.

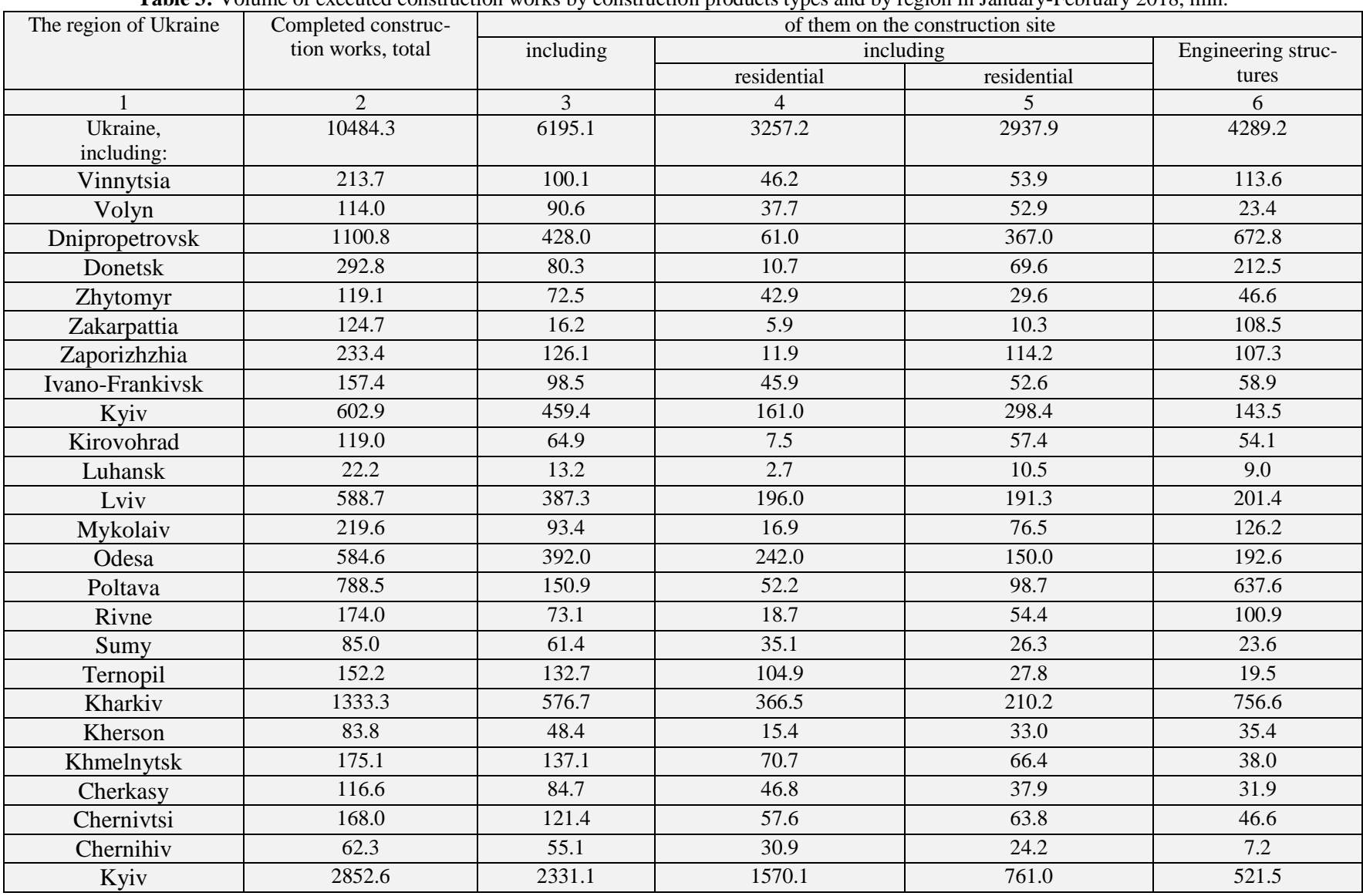

It is generalized by the authors for [18]

Instead this method became widespread in many European countries. Organizations that use it develop norms (standards) based on the possible market price of their products in such a way that the standard cost of production is significantly lower than the possible market price. which provides the required level of profitability.

The accounting method for full costs (absorption-costing) implies that all production costs (both variables and constants) are involved in the cost calculation of production. By this method. direct costs are attributed to the object of calculation. and overhead are distributed between the objects in proportion to the chosen base.
The method implies the inclusion the constant total costs production to the cost.

An alternative to traditional methods of calculation at full cost is calculation of the incomplete cost using method of direct costing and a cost calculation with variable costs - variable costing.

In accordance with direct costing method. only direct production costs are included in the cost of production. and all indirect costs are considered as expenses of the current period and are written off to the cost of sales. It is gradually becoming increasingly popular in construction. as it is expedient to apply a marginal cost 
Table 4: Ukraine's position in the Doing Business ranking in 2010-2018

\begin{tabular}{|c|c|c|c|c|c|c|c|c|c|c|}
\hline \multirow[t]{2}{*}{ No. } & \multirow[t]{2}{*}{ Indicator } & \multicolumn{9}{|c|}{ Ukraine's position in the Doing Business ranking } \\
\hline & & 2010 & 2011 & 2012 & 2013 & 2014 & 2015 & 2016 & 2017 & 2018 \\
\hline 1 & $\begin{array}{l}\text { Ease of doing } \\
\text { business }\end{array}$ & 142 & 145 & 152 & 137 & 112 & 96 & 83 & 80 & 76 \\
\hline 2 & $\begin{array}{c}\text { Starting a } \\
\text { Business } \\
\end{array}$ & 134 & 118 & 112 & 50 & 47 & 76 & 30 & 20 & 52 \\
\hline 3 & $\begin{array}{c}\text { Dealing with } \\
\text { Construction } \\
\text { Permits }\end{array}$ & 181 & 179 & 180 & 183 & 41 & 70 & 140 & 140 & 35 \\
\hline 4 & $\begin{array}{c}\text { Power Grids } \\
\text { Connection }\end{array}$ & 83 & - & 169 & 166 & 172 & 185 & 137 & 130 & 128 \\
\hline 5 & $\begin{array}{c}\text { Ownership } \\
\text { Registration }\end{array}$ & 141 & 164 & 166 & 149 & 97 & 59 & 61 & 63 & 64 \\
\hline 6 & $\begin{array}{l}\text { Credit Obtain- } \\
\text { ing }\end{array}$ & 30 & 32 & 24 & 23 & 13 & 17 & 19 & 20 & 29 \\
\hline 7 & $\begin{array}{c}\text { Investors Pro- } \\
\text { tection }\end{array}$ & 109 & 109 & 111 & 117 & 128 & 109 & 88 & 70 & 81 \\
\hline 8 & Taxation & 181 & 181 & 181 & 165 & 164 & 108 & 107 & 84 & 73 \\
\hline 9 & $\begin{array}{c}\text { International } \\
\text { Trade }\end{array}$ & 139 & 139 & 140 & 145 & 148 & 154 & 109 & 115 & 119 \\
\hline 10 & $\begin{array}{c}\text { Contracts } \\
\text { Enforcement }\end{array}$ & 43 & 43 & 44 & 42 & 45 & 43 & 98 & 81 & 82 \\
\hline 11 & $\begin{array}{c}\text { Enterprise } \\
\text { Liquidation }\end{array}$ & 145 & 150 & 156 & 157 & 162 & 142 & 141 & 150 & 149 \\
\hline
\end{tabular}

Developed by the authors for [19. 20].

accounting method in construction companies due to the volume of accounting works.

In the system of variable costing. constant total costs of production are excluded during calculating the costs.

The result of the improvement of the full cost calculation method is the ABC method. where overhead costs are allocated first among the main units. and then relate to the objects of calculation in proportion to the pre-selected base (as a rule. with direct labour costs). The application of this method is due to the need of the exact distribution of overhead costs. the identification of factors that affect their level. with an objective determination purpose of the certain products types cost. the correct formation of prices and determination of the production profitability.

In contemporary economic literature. significant attention is paid to the following methods of calculation: «just in time». targeting costing. kaisen costing. benchmarking. TQM. strategic cost accounting or «life-cycle costing». However. the method of applying them to construction companies has not been developed yet.

The «just in time» method implies the creation of a continuous current production. The purpose of this method is to reduce the costs that are associated with over-utilization of warehouse with final products. and the effective usage of the production potential of the enterprise. Such a method can not be used in the construction industry. because work is always performed for a particular customer. The targeting costing method is based on determining the market value of products that will be produced. then setting the desired profit margin. after it the determining the maximum allowable cost takes place. At this time. the cost of production is determined. and it will allow the company to receive the planned profit. only in condition to the availability of market prices.

The target costing system is based on the following principles: constant orientation to market's and customers' demand; calculation of target expenses for new products. as well as their constituent parts. which allows to achieve the planned profit under the existing market conditions; accounting of the influence on the cost price of the consumer's desires on the quality and terms of production; usage of the product life cycle concept.

This method is appropriate to be used at construction enterprises during preparatory work related to the choice of the concept of land development. In condition that possible market price of the sale is known. the construction company. deducting from it the desired profit. can determine the cost of object's construction.

Table 5: Generalized characteristic of traditional cost accounting and production costs calculation methods in the construction industry

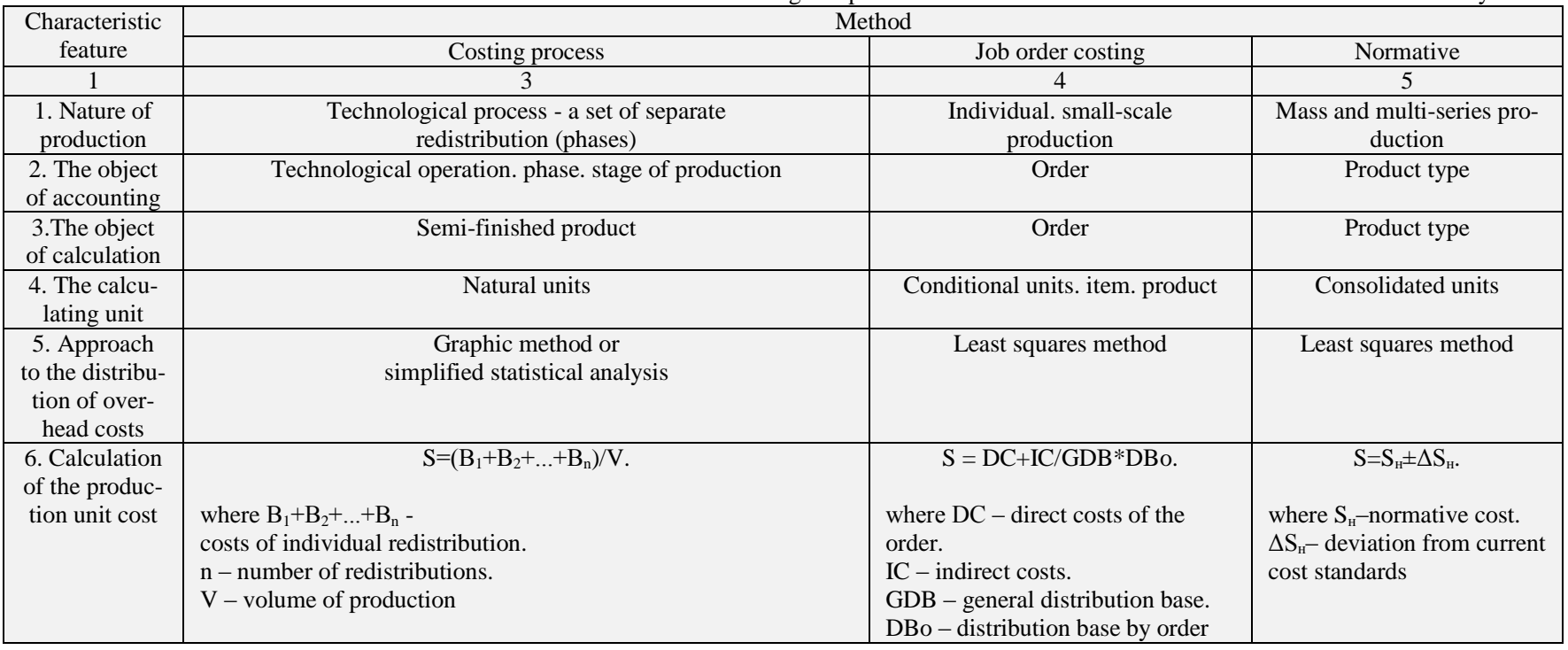




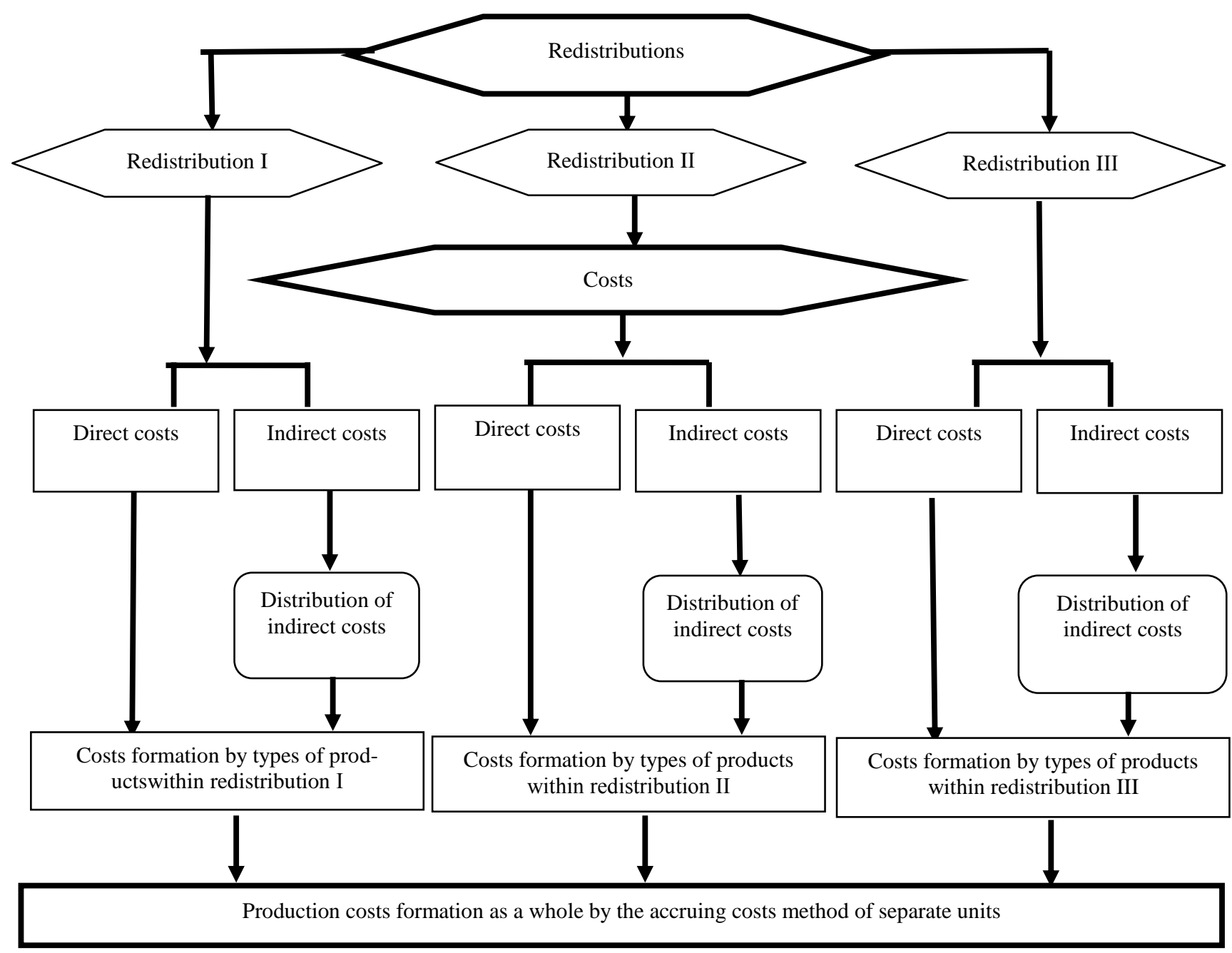

Fig.1: General scheme of construction cost accounting for production by process costing method (developed by the authors).

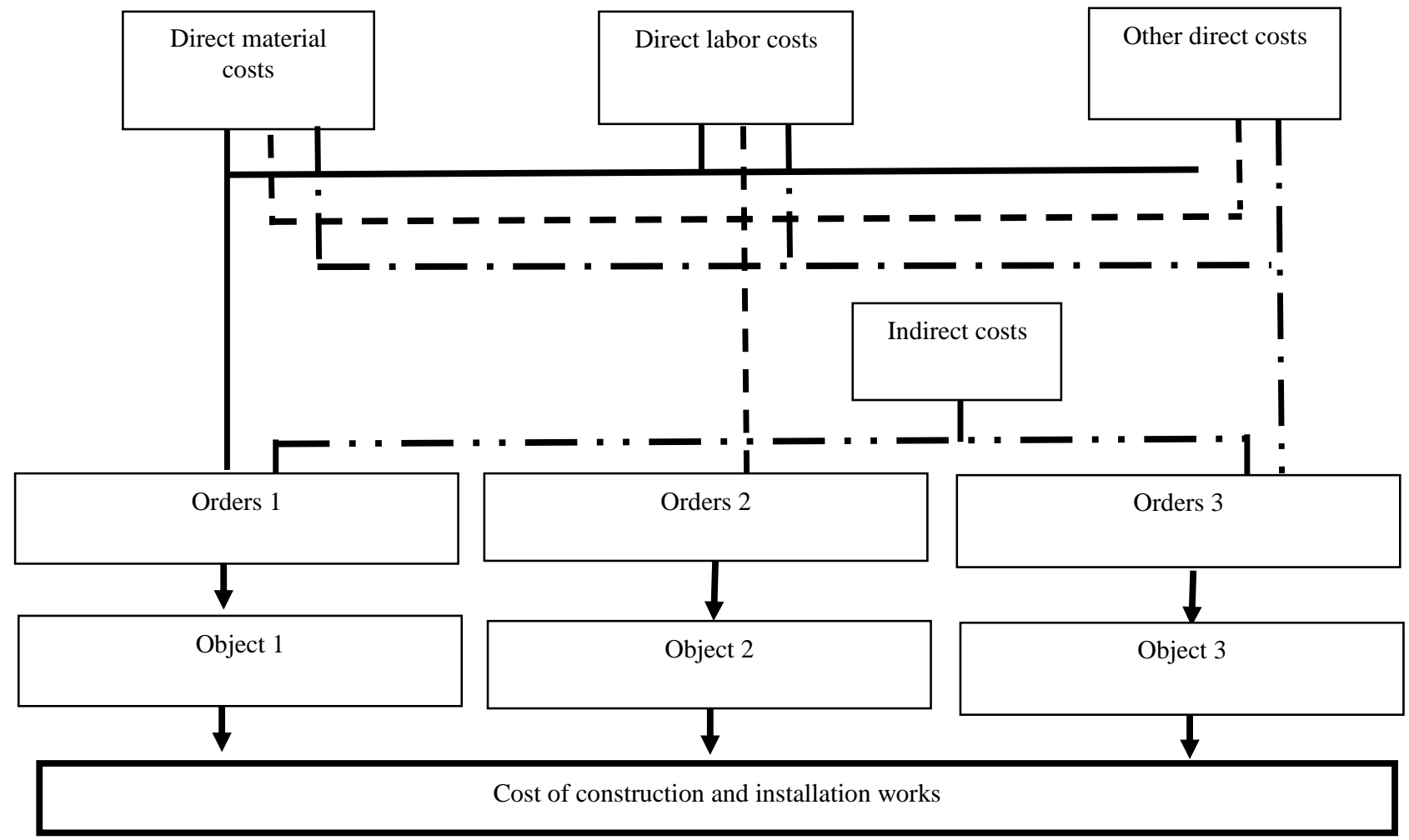

Fig. 2: Formation of the cost using job order method of accounting and calculation the costs of production (developed by the authors) 


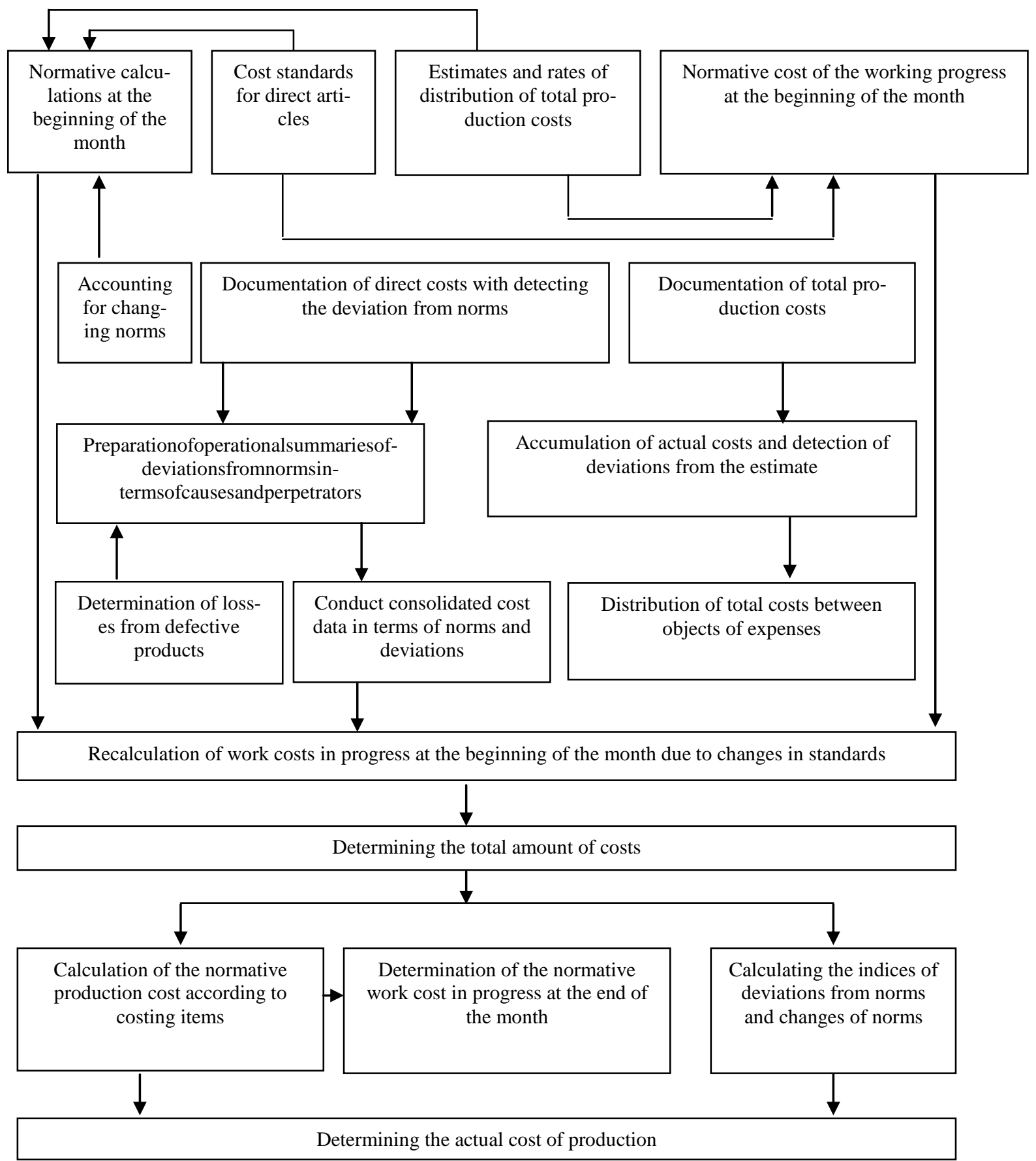

Fig. 3: Stages of the normative method of accounting and calculating the costs of production (developed by the authors)

Kaisen costing method is aimed at achieving the target cost. established in the application of the targeting costing method. due to the search for cheaper materials. insignificant

changes technology of construction. improving the mechanization level of labor and the development of workers.

Benchmarking and TQM systems provide a comparison of the cost management state and their level at the company with the indicators of enterprises-leaders in the industry and the subsequent use of advanced experience. To do this. the company identifies key performance indicators that it seeks to achieve. Because of the specifics of their work it is difficult for construction companies to create a balanced system of indicators. limiting the application in the construction industry of these methods.

Unlike benchmarking and TQM. the method of strategic cost management is precisely for construction companies. since it involves measuring actual costs associated with a particular object throughout all stages of its life cycle: research. development and design; construction; service.

\section{Conclusion}

The research has shown that the use of modern foreign calculation methods in the construction industry of Ukraine is hampered by factors such as the lack of proper regulatory and methodological support. outdated views on the calculation and management of companies. the lack of sufficient information on the introduction of advanced accounting methods for costs and calculating the cost of production (works. services) in the practice of managing. Therefore. in order to improve the formation of the construction cost in the construction industry. it is necessary to amend existing regulatory documents or to develop methodological recommendations for the use in the construction industry of calculation methods. in particular. targeting costing. kaisen costing method. benchmarking. TQM. strategic cost management. The development of these recommendations will be the subject of further research. 


\section{References}

[1] Pavelko O.V.. "Vytraty u budivnytstvi: identyfikatsiia ekonomichnoi sutnosti. normatyvno-pravove rehuliuvannia obliku ta vidobrazhennia u zvitnosti”. Visnyk ZhDTU. No 4 (78). (2016). pp. 93-101 (In Ukrainian)

[2] National (provision) accounting standard 1 "General requirements for financial reporting" // Order of the Ministry of Finance of Ukraine from 07.02.2013 number 73. [Electronic resource]. - Mode of access: http: // zakon.rada.gov.ua

[3] Methodological recommendations for the formation of the cost of construction and installation works // Order of the Ministry of Regional Development and Construction of Ukraine dated December 31. 2010 No. 573. [Electronic resource]. - Mode of access: http://msmeta.com.ua/file/Metoduchni\%20rекоменzii.pdf.

[4] Verkhohliadova N.I.. Borodin M.O.. Nehoda A.S.. "Problema efektyvnoi sobivartosti budivelno-montazhnykh robit na suchasnomu etapi rozvytku budivelnoi industrii Ukrainy". Molodyi vchenyi. No 4 (31). kviten. (2016). pp. 31-34. (In Ukrainian)

[5] Kononova O. Ye.. Prosenko K. I.. Udoskonalennia orhanizatsii obliku vytrat budivelnoho pidpryiemstva. Naukovyi visnyk Uzhhorodskoho natsionalnoho universytetu. - Vol 6. chastyna 2.- (2016). pp. 23-27. (In Ukrainian)

[6] Iliashenko V. A.. Yukhnovska Yu. O.. "Orhanizatsiia obliku vytrat kalkuliuvannia sobivartosti v budivnytstvi”. Derzhava ta rehiony. No 1. (2013). pp. 110-113. (In Ukrainian)

[7] Davydiuk T. V.. "Metody obliku vytrat i kalkuliuvannia sobivartosti produktsii u vitchyznianykh normatyvnykh aktakh: napriamyudoskonalennia". Ekonomika: realii chasu. No1. (2016). pp. 613

[8] Radchenko K.. Analiz metodiv kalkuliuvannia ta yikh zastosuvannia v riznykh haluziakh promyslovosti. Ekonomika. No 130. (2011). pp. 63-65 (In Ukrainian)

[9] Skrypnyk M.I. "Metody obliku vytrat i metody kalkuliuvannia: sutnist i spivvidnoshennia". Mizhnarodnyi zbirnyk naukovykh prats. Vol. 2(14). pp. 202-206. (In Ukrainian)

[10] Pyrets N.M.. Chernenko T.V.. "Metody vyznachennia sobivartosti produktsii pidpryiemstva budivelnoi haluzi v systemi upravlinskoho obliku”. Ekonomichnyi prostir. No 71. (2013). pp. 231-238. (In Ukrainian)

[11] Jianqiang Tang.. "Cost Management of Construction Project based on Activity-based". Costing International Conferenceon Civil "Ma terials and Environmental Sciences”. Sichuan Agricultural University. Chengdu. 610000. China. (CMES 2015). - pp. 51-54.

[12] Carolin Bahr. Kunnibert Lennerts. "Quantitative validation of budgeting method. Suggestion of a new calculation method for determination of maintenance costs". Journal of Facilities Management Vol. 8 Issue: 1. pp. 47-63.

[13] Agnieszka Leśniak. Edyta Plebankiewicz. Krzysztof Zima “Cost Calculation of Building Structures and Building Works in Polish Conditions". Engineering Management Research; Vol. 1. No. 2; (2012). pp.72 -81.

[14] Ivanytska T.Ie. "Analiz metodiv obliku vytrat i kalkuliuvannia sobivartosti produktsii budivelnoho pidpryiemstva". Skhidna Yevropa: ekonomika. biznes ta upravlinni. Vol. 1 (01). (2016). pp. 129-134.

[15] http://www.ukrstat.gov.ua/operativ/operativ2016/ bud/ibpvuk/ibpvuk_u/ibp_uk_bk_u.htm

[16] http://www.ukrstat.gov.ua/operativ/operativ2014/bud/ovb/ovb_u/ov b_rik_u_bez.htm.

[17] http://www.ukrstat.gov.ua/operativ/operativ2016/bud/bpvuk/ibpvuk _u/ibp_uk_bk_vyd_u.htm.

[18] http://www.ukrstat.gov.ua/operativ/operativ2018/bud/ovb_reg/ovb_ reg_u/ovb_reg_0218_u.htm.

[19] http://www.doingbusiness.org/ /media/WBG/Doing Business/Documents/Annual-Reports/English/DB2018-Full-Report.pdf.

[20] http://gtmarket.ru/news.

[21] Vakhrushyna M. A. "Bukhhalterskyi upravlinskyi oblik”. Pidruchnyk dlia studentiv vuziv. yaki navchaiutsia za ekon. Spetsialnostiamy. M .: Omeha-L. (2005). 576 p. 